\title{
Evaluation of Retinal Morphology and Contrast Sensitivity Function in Patients with Restless Legs Syndrome
}

\author{
Huzursuz Bacaklar Sendromlu Hastalarda Retina Morfolojisi ve Kontrast Duyarlilik \\ Fonksiyonunun Değerlendirilmesi
}

\author{
(1) Mustafa Çam¹, (1) Aydın Yıldız², () Sedat Arıkan³ \\ ${ }^{1}$ Canakkale Onsekiz Mart University Faculty of Medicine, Department of Neurology, Canakkale, Turkey \\ 2Beylikduzu State Hospital, Clinic of Ophthalmology, Istanbul, Turkey \\ ${ }^{3}$ Canakkale Onsekiz Mart University Faculty of Medicine, Department of Ophthalmology, Canakkale, Turkey
}

\begin{abstract}
Objective: The decreased number of dopamine receptors in the putamen are considered to play an important role in the pathophysiology of restless legs syndrome (RLS). Retinal dopamine plays an important role in contrast sensitivity (CS) by establishing communication between retinal cells. It is also suggested that retinal dopaminergic neurons protect other retinal neurons. In this study, we aimed to investigate the thickness of retinal layers and CS function (CSF) of patients with RLS.

Materials and Methods: A total of 68 participants were included in this prospective case-control study. The participants were divided into two groups as those with RLS ( $n=35)$ in group 1 and control subjects $(n=33)$ in group 2. Optical coherence tomography was used to measure central macular thickness, retinal nerve fiber layer thickness (RNFL), and retinal ganglion cell inner plexiform layer thickness (GCIPL). RNFL thickness was measured as average and as sectoral (superior, inferior, nasal and temporal). Additionally, the CS test measured at all spatial frequencies of 1.5, 3, 6, 12 and 18 cycle per degree (cpd) was performed in all participants.

Results: The average and superior sectoral RNFL thicknesses in group 1 were statistically significantly thinner than group 2 ( $\mathrm{p}=0.03$ and $\mathrm{p}=0.01$ respectively). However, the thicknesses of other RNFL sectors were not different between group 1 and group 2 . There were no statistically significant differences between group 1 and group 2 regarding the thicknesses of GCIPL and central macula. The mean values of CSF at all spatial frequencies of $1.5 \mathrm{cpd}, 3 \mathrm{cpd}, 6 \mathrm{cpd}, 12 \mathrm{cpd}$ and 18 cpd were statistically significantly higher in group 2 in comparison to group 1 ( $\mathrm{p}<0.001$ for all spatial frequencies).
\end{abstract}

Conclusion: The decreased thickness of retinal layers and reduced CSF in patients with RLS support retinal dopaminergic dysfunction.

Keywords: Restless legs, retinal nerve fiber, contrast sensitivity

Öz

Amaç: Putamendeki azalmış dopamin reseptör sayısı, huzursuz bacak sendromu (HBS) patofizyolojisi için önemli bir neden olarak kabul edilmiştir. Retina dopamin, retina hücreleri arasında iletişim kurarak kontrast duyarlılı̆̆ında (CS) önemli bir rol oynar. Ayrıca retinal dopaminerjik nöronların diğer retina nöronlarını koruduğu öne sürülmektedir. Bu çalışmada HBS hastalarının retina tabakalarının kalınlığını ve CS fonksiyonunu (CSF) araştırmayı amaçladık.

Gereç ve Yöntem: Bu çalışma ileriye dönük ve olgu kontrollü olup, katılımcı sayısı 68'dir. HBS'li (n=35) hasta ve sağlıklı katılımcı (n=33) olmak üzere iki grup hasta vardır.

Optik koherens tomografi, merkezi maküler kalınlık, retina sinir lifi tabakası kalınlığı (RSLT) ve retina ganglion hücresi iç pleksiform tabaka kalınlığını (GCIPL) ölçmek için kullanıldı. RSLT kalınlığ1 ortalama ve sektörel (üst, alt, nazal ve temporal) olarak ölçüldü.

Bulgular: Grup 1'de ortalama ve üst sektörel RSLT kalınlı̆̆1, grup 2'ye göre istatistiksel olarak anlamlı derecede daha ince idi (sırasıyla; p=0,03 ve p=0,01). Bununla birlikte, diğer RSLT sektörlerinin kalınlıkları grup 1 ve grup 2 arasında farklı değildi. Grup 1 ve grup 2 arasında GCIPL ve merkezi maküla kalınlıkları açısından istatistiksel olarak anlamlı bir fark yoktu. Öte yandan, 1,5 derece başına döngü (cpd), 3 cpd, 6 cpd, 12 cpd ve 18 cpd gibi tüm uzamsal frekanslarda CSF'nin ortalama değerleri grup 2'de grup 1'e kıyasla istatistiksel olarak anlamlı derecede yüksekti (tüm uzaysal alanlarda p<0,001) frekanslar).

Sonuç: RLS hastalarında retina katmanlarının kalınlığı ve CSF'nin azalması retinal dopaminerjik disfonksiyonu destekleyebilir. Ek olarak non-invaziv olarak uygulanan bir OKT incelemesi HBS hastalarının tanı ve takibinde fayda sağlayabilir.

Anahtar Kelimeler: Huzursuz bacaklar, retinal sinir lifi, kontrast duyarlılı̆̆

Address for Correspondence/Yazışma Adresi: Lect. Mustafa Çam MD, Canakkale Onsekiz Mart University Faculty of Medicine, Department of Neurology, Canakkale, Turkey

Phone: +90 5066493267 E-mail: mustafacam20@ hotmail.com ORCID: orcid.org/0000-0003-3116-203X

Received/Geliş Tarihi: 09.03.2021 Accepted/Kabul Tarihi: 17.02.2022

${ }^{\circ}$ Copyright 2022 by Turkish Neurological Society

Turkish Journal of Neurology published by Galenos Publishing House. 


\section{Introduction}

Restless legs syndrome (RLS) is a sensorimotor disorder, also known as Willis-Ekbom disease, characterized by the urge to move the legs $(1,2)$. The symptoms usually occur at night, worsen with rest, and recover with movement (3). It is reported that the incidence of RLS in the general population varies between 1-15\% (2). Current evidence emphasizes the role of dopaminergic system dysfunction and changes in the control of iron homeostasis in the central nervous system (4). In addition, there are studies showing that genetic factors, inflammatory-infectious factors, opioid system dysfunction, and thalamic dysfunction also play role in $\operatorname{RLS}(5,6)$. The improvement of symptoms with the use of dopamine agonists and worsening of them with the use of dopamine antagonists in patients with RLS indicate the importance of dopamine in the pathophysiology of RLS (7). Dopamine is abundantly available in retinal neurons, and provides interactions between amacrine cells, horizontal cells, ganglion cells, and photoreceptors to form spatial contrast sensitivity (CS) for clear vision. It was reported that dopamine also playes a role in retinal function. However, it is not yet exactly known how dopaminergic deficiency affects the retina (8).

The types of dopamine receptors in the retina were suggested to be the same as those in the brain (9). Recent studies performed using optical coherence tomography (OCT) revealed the thinning of retinal nerve fiber layer (RNFL) in patients with Parkinson's disease (PD), suggesting that the dopaminergic activity in retinal neurons might also be adversely affected in patients with PD. A reasonable pathophysiological mechanism for the protective role of dopamine for retinal neurons was reported to be due to the induction of neurotrophic factors by dopamine (10). Dopamine is also the most important catecholamine in the retina, in which there are more enzymes that both synthesize and catabolize dopamine. The RNFL forms one of the layers of the neurosensory retina, and it is reported that analysis of RNFL thickness by using OCT is useful for showing axonal degeneration in the neuronal retina in the early stages of disease (11). In the study by Kose Ozlece et al. (12), RNFL analysis was conducted with OCT and RNFL thickness was reported to be significantly thinner in patients with RLS compared to the control group. In visual pathways, retinal photoreceptor cells form the first order neurons that transmit visual information to retinal ganglion cells (RGC) through bipolar cells. The fibers of the optic nerve are formed by the axons of the RGCs. Therefore, decreases in either RGCs or RNFL thickness can cause impairment of optic nerve functions such as color vision, bright vision and sharp vision [contrast sensitivity (CS)], in addition to attenuation of visual acuity that is the most important function of RGCs. However, it is also stated that there may be early deterioration of these functions, especially in CS, which contributes to visual quality rather than visual acuity level (13). A search of the literature indicated that only one study examined retinal morphology and CS function (CSF) in patients with RLS Koskderelioglu et al. (14).

This study aimed to evaluate retinal morphology and CSF in patients with RLS to gain insight into the importance of dopaminergic function on retinal layer structures and visual quality.

\section{Materials and Methods}

This was a prospective case-control study comparing patients with RLS and control subjects. The study protocol was approved by the Ethical Committee of Canakkale Onsekiz Mart University (decision no: 2019-18, date: 13.11.2019). Patients diagnosed as having idiopathic RLS according to the International Classification of Sleep Disorders-Third Edition were included in the study. As CS could be affected by any change in retinal morphology, subjects with diabetes, any history of systemic diseases that might affect eye health such as nephropathy, neurological disease, rheumatological disease, and hematological disease, those with changes that disrupted corneal, lens and vitreous transparency and layout such as corneal opacity, keratoconus, pterygium, cornea dystrophies, cataracts, vitreous opacity, those with any macular degeneration, including diabetic retinopathy, hypertensive retinopathy, and agerelated macular degeneration, those with central serous retinopathy and solar retinopathy and those with a previous history of intraocular surgery and refractive surgery were not included in the study. Patients with signs of vascular problems and hypoxia were excluded from the study. Newly diagnosed patients were included in our study. After the necessary measurements were made by the eye department, treatment was started.

The examinations of participants were made in the neurology and ophthalmology outpatient clinics. The participants who met the inclusion criteria were clearly informed about all steps in the study and written informed consent was obtained from those who willingly wanted to participate in this study. Within the scope of participants' routine eye examinations in the ophthalmology outpatient clinic, measurements of best corrected visual acuity (BCVA) and intraocular pressure were made by using an autorefractometer and air-blow tonometer, respectively. Additionally, the assessments of anterior segment structures of the eye such as cornea and lens and posterior segment structures of eye such as optic nerve head and retina were performed via biomicroscopic and fundus examination, respectively. After completing routine eye examination, the participants whose BCVA was equal to or higher than 20/20 and at the same time without any eye disorder except refractive error were subjected to retinal scan OCT assessment in order to evaluate the thicknesses of the RGC inner plexiform layer (GCIPL) and peripapillary RNFL of the macula lutea. Tear meniscus height was also evaluated with the anterior segment mode of OCT to exclude dry eye syndrome. All OCT measurements were performed with the Zeiss Cirrus 5000 HD-OCT, USA device.

In the final stage of the study, the CS levels of participants were evaluated with a non-invasive and non-contact Optec 6500 device in day light mode. During this assessment, each eye was evaluated separately. When performing the CS test, participants were asked whether the gray lines on the white background present in the device's program were oriented upward, downward, to the right, to the left, or in the horizontal plane. If the participant's answer was the same as the direction as the card in the tester's hand, the participant was considered to achieve that level of CS and passed to the next, more difficult level, in which the shade of gray was brought closer to white. After CS functions at all spatial 
frequencies of 1.5 cycle per degree (cpd), $3 \mathrm{cpd}, 6 \mathrm{cpd}, 12 \mathrm{cpd}$ and 18 cpd were analyzed, the amount of CS was calculated with a nomogram compatible with the device.

\section{Statistical Analysis}

The thicknesses of RNFL and GCIPL were statistically compared in terms of reflecting retinal morphology and the levels of CS were compared in terms of reflecting retinal function of the patients with RLS and control subjects.

The SPSS (Statistical Package for the Social Sciences) 21.0 package program was used for analysis of the data. The distributions of all parameters including RNFL thickness, GCIPL thickness and CS levels measured at all spatial frequencies were evaluated by using Shapiro-Wilk test. Because these parameters did not have normal distribution, the Mann-Whitney U test was used to statistically compare them between patients with RLS and control subjects. The statistical results were reported as mean + standard deviation. A p value of $<0.05$ was accepted as statistically significant.

\section{Results}

Thirty-five patients with RLS and 33 age- and gender-matched control subjects were included in this study. The participants were divided into two groups as patients with RLS in group $1(n=35)$ and control subjects in group $2(n=33)$. The mean age of group 1 and group 2 was 34 and 33 years, respectively, and there was no statistically significant difference between the two groups in terms of the age $(\mathrm{p}=0.4)$. The age range was $25-50$ in group 1 and 23-49 in group 2. While the male/female ratio was $83 \%$ in group 1, it was $80 \%$ in group 2. Regarding the comparison of RNFL thickness between the two groups, average RNFL thickness $(79+1.2$ in group 1 vs. $80+2.0$ in group $2, \mathrm{p}=0.01)$ and superior sectorial RNFL thickness $(106.5+2.5$ in group 1 vs. $114.5+2.6$ in group $2, \mathrm{p}=0.03$ ) were found to be statistically significantly lower in group 1 compared to those in group 2. Although the minimum and average RGC thicknesses and central macular thicknesses were lower in group 1 , there was no statistically significant difference

Table 1. The comparison of sectorial and average retinal nerve fiber layer thicknesses, retinal ganglion cell thickness, and central macular thickness between patients with restless legs syndrome (group 1) and healthy subjects (group 2)

\begin{tabular}{llll} 
& $\begin{array}{l}\text { Group 1 } \\
\text { Mean } \pm \text { SD }\end{array}$ & $\begin{array}{l}\text { Group 2 } \\
\text { Mean } \pm \text { SD }\end{array}$ & p value \\
\hline Superior RNFL $(\mu \mathrm{m})$ & $106.3 \pm 2.5$ & $114.5 \pm 2.6$ & 0.03 \\
\hline Inferior RNFL $(\mu \mathrm{m})$ & $116.6 \pm 2.7$ & $121.4 \pm 2.2$ & 0.06 \\
\hline Nasal RNFL $(\mu \mathrm{m})$ & $68.5 \pm 1.6$ & $67.6 \pm 2.4$ & 0.9 \\
\hline Temporal RNFL $(\mu \mathrm{m})$ & $61.0 \pm 1.5$ & $65.7 \pm 1.7$ & 0.06 \\
\hline Average RNFL $(\mu \mathrm{m})$ & $79.0 \pm 1.2$ & $80.0 \pm 2.0$ & 0.01 \\
\hline Minimum RGC $(\mu \mathrm{m})$ & $72.3 \pm 2.0$ & $73.6 \pm 2.9$ & 0.08 \\
\hline $\begin{array}{l}\text { Mean RGC } \\
\text { Central macular }\end{array}$ & $249.0 \pm 1.2$ & $80.0 \pm 2.0$ & 0.08 \\
\hline $\begin{array}{l}\text { Rhickness }(\mu \mathrm{m}) \\
\text { RNFL: Retinal nerve fiber } \\
\text { deviation }\end{array}$ & layer, RGC: Retinal & ganglion cell, & SD: Standard \\
\hline
\end{tabular}

between the two groups in terms of these measurements (Table 1).

In patients with RLS, CS was determined to significantly decrease at all spatial frequencies compared to the control subjects. Additionally, there was no statistically significant difference between the two groups in terms of tear meniscus heights $(p>0.05)$ (Table 2).

\section{Discussion}

The retina is an effective region with respect to both the synthesis and catabolism of dopamine (9). Therefore, in recent years, the detection of retinal degeneration with OCT has become important in diseases affecting dopaminergic pathways (15).

In a cross-sectional study by Koskderelioglu et al. (14) in 36 patients with RLS and 36 control subjects, significant thinning was shown in average RNFL and total retinal layers compared to the control group, and it was concluded that this retinal thinning in the macular region supported dopaminergic dysfunction in patients with RLS. In a similar study, Kose Ozlece et al. (12) also showed that foveal thickness in patients with RLS was thinner compared to the control group. They found that this difference was statistically significant in the superior, inferior and temporal sectors of the macula. They also showed that these changes were related to the duration of disease and that the longer the duration, the greater the degree of thinning (12).

In the present study, the average RNFL and superior RNFL values were statistically significantly lower in patients with RLS than in control subjects. This result of the present study is important because it supports the results of the aforementioned studies arguing in favor of the possibility of retinal dopaminergic dysfunction in patients with RLS. On the other hand, no statistically significant difference was reported between patients with RLS and control subjects regarding RNFL thickness and GCIPL thickness in a similar study by Tak et al. (8). However, they suggested that the decrease in Montreal Cognitive Assessment score in patients with RLS might indicate dopaminergic dysfunction independent of anatomical impairment (16). Therefore, it is conceivable to consider that the clinical findings of dopaminergic dysfunction may also be seen before an obvious anatomical disorder emerges. In

Table 2. The comparison of contrast sensitivity function measured at all spatial frequencies and tear meniscus height between patients with restless legs syndrome (group 1) and healthy subjects (group 2)

\begin{tabular}{|llll} 
& $\begin{array}{lll}\text { Group 1 } \\
\text { (Restless } \\
\text { legs } \\
\text { sydrome, } \\
\mathbf{n}=35)\end{array}$ & $\begin{array}{l}\text { Group 2 } \\
\text { subject, } \\
\mathbf{n}=33)\end{array}$ & $\begin{array}{l}\mathrm{p} \\
\text { value }\end{array}$ \\
& $158.4 \pm 9.8$ & $159.8 \pm 9.6$ & 0.8 \\
\hline Tear meniscus height $(\mu \mathrm{m})$ & $37.9 \pm 1.8$ & $71.4 \pm 3.0$ & $<0.001^{*}$ \\
\hline A (1.5)-cpd & $58.8 \pm 2.8$ & $101.0 \pm 4.7$ & $<0.001^{*}$ \\
\hline B (3)-cpd & $59.4 \pm 2.7$ & $117.8 \pm 5.9$ & $<0.001^{*}$ \\
\hline C (6)-cpd & $26.0 \pm 1.4$ & $51.5 \pm 2.6$ & $<0.001^{*}$ \\
\hline D (12)-cpd & $10.0 \pm 0.6$ & $19.5 \pm 2.9$ & $<0.001^{*}$ \\
\hline E (18)-cpd & & & \\
\hline
\end{tabular}

cpd: Cycle per degree 
another similar study, although no significant difference was found between the groups in terms of RNFL and macular thickness, subfoveal, temporal and nasal choroid thicknesses were found to be significantly thinner in the RLS group (17).

CSF of the eye can be defined as the ability to discriminate an object on a similar-colored background. Therefore, CSF of the eye enables fine and detailed vision. The examination of visual acuity may not provide an idea about the fine visual potential because it is usually measured at high spatial frequency such as $30 \mathrm{cpd}$; however, the measurement in CS testing involves low, medium and high spatial frequencies of the eye, so that it is valuable in terms of evaluating visual quality. In visual processing, the network is formed by photoreceptors, bipolar cells, amacrine cells, horizontal cells and RGCs and subsequently the interaction between retinal nerve fibers and the lateral geniculate body plays a significant role in CSF. Hence, CS testing becomes a valuable tool for contributing to assessment of optic nerve and retinal function (10). Dopamine is an important neurotransmitter within the network for CS formation, particularly by adjusting on-off phenomena of RGCs. Dopaminergic dysfunction was robustly considered in the pathogenesis of RLS in several previous studies, and for this reason CS testing might benefit the explanation of pathogenesis in RLS. Additionally, neuro-ophthalmological disorders, age, cataract, glaucoma, diabetic retinopathy, drugs, and toxic chemicals were shown to affect CS $(16,18)$. In order to evaluate CSF in neurological disorders including RLS, firstly the factors arising from ophthalmological diseases that can affect CSF should be excluded. Since dry eye syndrome was known as one of the most important causes of CS impairment due to deterioration of the corneal surface, tear meniscus height of the subjects was evaluated to rule out dry eye syndrome. In the present study, the presence of similar tear meniscus height values in both groups was important in terms of ruling out the effect of dry eye syndrome on CS. To the best of our knowledge, there is only one study associating RLS with CS in the literature Koskderelioglu et al. (14). In their study, although a significant difference was found between patients with RLS and control subjects in terms of RNFL thickness, they reported no significant difference between patients with RLS and control subjects regarding CS at all spatial frequencies measured using the Pelli-Robson CS chart. This chart was a different technique than the functional acuity contrast test that was used in our study. Similar to previous studies in the literature, the decrease in sectorial RNFL thickness was demonstrated by OCT in our study $(8,12,14,15,17)$. In the present study, the effect of this damage on CS was also shown. In the current study, the finding of a significant reduction in CS at all spatial frequencies in patients with RLS supports the idea that impairment of visual quality can be a result of decreased retinal function due to dopamine dysfunction. However, further studies involving larger sample sizes are warranted to confirm this association. The effect of treatment of RLS on CS level, namely on visual quality, is a matter of curiosity.

\section{Study Limitations}

There are important limitations of the present study. Since the information provided by the patients about the duration of the disease was subjective, no statistical analysis could be made between duration and systemic exposure. Ferritin level was 11.5 $\mathrm{ng} / \mathrm{ml}$ in group 1 and it was $22 \mathrm{ng} / \mathrm{ml}$ in group 2, and there was no statistically significant difference between the two groups. The study was based on investigating CS due to possible dopaminergic effects in patients with RLS. Changes due to ferritin, vitamin B12 and other possible causes were not studied. Smoking and alcohol use were not included in the exclusion criteria. Although the number of patients included in the study was similar to other studies in the literature, performing the study with larger series could deliver more meaningful results. Long-term follow-up of these patients and repeated OCT and CS assessments will serve to show how effective these tests are in relation to prognosis.

\section{Conclusion}

In conclusion, RNFL thickness and CS at each spatial frequency can decrease in patients diagnosed with RLS. Both parameters are easy to examine because they are non-contact and non-invasive. Long-term follow-up and prospective studies are needed with large series to evaluate the relationship between these parameters particularly with respect to the severity and duration of disease.

\section{Ethics}

Ethics Committee Approval: The study protocol was approved by the Ethical Committee of Canakkale Onsekiz Mart University (decision no: 2019-18, date: 13.11.2019).

Informed Consent: Written informed consent.

Peer-review: Externally and internally peer-reviewed.

\section{Authorship Contributions}

Concept: A.Y., Design: M.Ç., S.A., Data Collection or Processing: A.Y., Analysis or Interpretation: M.Ç., A.Y., S.A., Literature Search: M.Ç., A.Y., S.A., Writing: M.Ç., A.Y., S.A.

Conflict of Interest: No conflict of interest was declared by the authors.

Financial Disclosure: The authors declared that this study received no financial support.

\section{References}

1. Baier PC, Trenkwalder C. Circadian variation in restless legs syndrome. Sleep Med 2007;8:645-650.

2. Filiz MB, Çakir T. Restless legs syndrome with current diagnostic criteria. Türk Osteoporoz Derg 2015;21:87-95.

3. Acar S, Gencer AM. Genetics in restless legs syndrome. Turk J Phys Med Rehab 2005;51:156-160.

4. Rezvani F, Sayadnasiri M, Rezaei O. Restless legs syndrome in patients infected with Helicobacter pylori. Neurol Res 2018;40:581-585.

5. Hüseyinoğlu N. Current developments in restless legs syndrome .Türkiye Klinikleri J Pulm Med-Special Topics 2018;11:263-269.

6. Weinstock LB, Walters AS, Paueksakon P. Restless legs syndrome-theoretical roles of inflammatory and immune mechanisms. Sleep Med Rev 2012;16:341-354.

7. Bogan RK. From bench to bedside: an overview of rotigotine for the treatment of restless legs syndrome. Clin Ther 2014;36:436-455.

8. Tak AZA, Çelik M, Kalenderoğlu A, et al. Evaluation of optical coherence tomography results and cognitive functions in patients with restless legs syndrome. Noro Psikiyatr Ars 2018;56:243-247.

9. Chorostecki J, Seraji-Bozorgzad N, Shah A, et al. Characterization of retinal architecture in Parkinson's disease. J Neurol Sci 2015;355:44-48.

10. Witkovsky P. Dopamine and retinal function. Doc Ophthalmol 2004; 108:17-40

11. Bittersohl D, Stemplewitz B, Keserü M, et al. Detection of retinal changes in idiopathic Parkinson's disease using high-resolution optical coherence tomography and heidelberg retina tomography. Acta Ophthalmol 2015;93:e578-e584. 
12. Kose Ozlece H, Solmaz V, Özal SA, Çelik Y. Do you have restless leg syndrome? I understood from your eyes. Sleep Breath 2019;23:551-557.

13. Plainis S, Anastasakis AG, Tsilimbaris MK. The value of contrast sensitivity in diagnosing central serous chorioretinopathy. Clin Exp Optom 2007;90:296-298.

14. Koskderelioglu A, Kusbeci T, Kusbeci OY, Gedizlioglu M. Optic nerve head, retinal nerve fiber layer and macular thickness analysis in restless legs syndrome. Parkinsonism Relat Disord 2016;31:110-115.

15. Satue M, Garcia-Martin E, Fuertes I, et al. Use of Fourier-domain OCT to detect retinal nerve fiber layer degeneration in Parkinson's disease patients. Eye (Lond) 2013;27:507-514.
16. Marmor MF, Gawande A. Effect of visual blur on contrast sensitivity. Clinical implications. Ophthalmology 1998;95:139-143.

17. Kocasarac C, Yigit Y, Trotti LM, Basaran S. Ocular morphological changes in patients with restless legs syndrome analyzed by optical coherence tomography. Sleep Med 2019;57:1-5.

18. Ross JE, Clarke DD, Bron AJ. Effect of age on contrast sensitivity function: uniocular and binocular findings. Br J Ophthalmol 1985;69:51-56. 